\title{
Efek Seduhan Kopi (Coffea Cenephora) dan Teh Hitam (Camellia Sinensis L) Terhadap Gambaran Histopatologis Ginjal Tikus Putih
}

\author{
Didik Eka Saputra, Fitria Diniah Janah Sayekti \\ Program Studi Sarjana Terapan Teknologi Laboratorium Medis, Sekolah Tinggi Ilmu Kesehatan Nasional
}

\begin{abstract}
Abstrak
Kopi dan teh merupakan salah satu minuman paling populer di Indonesia. Dalam kopi dan teh terdapat kandungan kafein. Kafein aman untuk dikonsumsi namun jika dikonsumsi secara berlebihan dapat menimbulkan gangguan pada organ ginjal. Batas maksimum kafein dalam makanan dan minuman yang diperbolehkan adalah $150 \mathrm{mg} / \mathrm{hari}$. Tujuan penelitian ini adalah untuk mengetahui pengaruh histopatologi pada ginjal tikus putih Rattus norvegicus setelah pemberian seduhan kopi (Coffea cenephora), dan teh hitam (Camellia sinensis L). Penelitian ini merupakan penelitian eksperimental dengan 7 kelompok perlakuan yaitu 1 kontrol, 3 perlakuan kopi dan 3 perlakuan teh. Jaringan ginjal diamati secara makroskopis dan mikroskopis. Hasil uji Mann-Whitney nilai asymp.Sig $<0,05$. menunjukkan bahwa terdapat perbedaan yang signifikan antara kelompok perlakuan seduhan kopi dan teh dengan kelompok kontrol (tanpa perlakuan). Seduhan kopi dan teh hitam dapat memberikan efek terhadap gambaran histopatologi ginjal tikus putihberupa degenerasi dan piknotik dan semakin tinggi dosis seduhan yang diberikan semakin besar efek kerusakan yang terjadi.
\end{abstract}

Kata Kunci : kopi, teh, ginjal, makroskopis, histopatologi

\section{Effect of Infusion Coffee (Coffea cenephora) and Black Tea (Camellia sinensis L) on Kidney Histopathological in White Rats}

\begin{abstract}
Coffee and tea are one of the most popular drinks in Indonesia. Coffee and tea contain caffeine. Caffeine is safe for consumption but if consumed in excess it can cause kidney problems. The maximum limit of caffeine in foods and beverages allowed is $150 \mathrm{mg} / \mathrm{day}$. The purpose of this study was to determine the histopathological effect on the kidneys of white rats Rattus norvegicus after steeping coffee (Coffea cenephora) and black tea (Camellia sinensis L). This study is an experimental study with 7 treatment groups, namely 1 control, 3 coffee treatments and 3 tea treatments. Kidney tissue was observed macroscopically and microscopically. The results of the Mann-Whitney test asymp.Sig value $<0.05$. showed that there was a significant difference between the coffee and tea steeping treatment group and the control group (without treatment). Infusion of coffee and black tea can have an effect on the histopathological picture of the kidneys of white rats in the form of degeneration and pyknotic and the higher the steeping dose given, the greater the damage effect.
\end{abstract}

Keywords: : Coffee, Tea, Kidney, Macroscopic, histopatology

Korespondensi : Fitria Diniah Janah Sayekti, Program Studi Sarjana Terapan Teknologi Laboratorium Medis Sekolah Tinggi Ilmu Kesehatan Nasional Surakarta, Jalan Raya Solo-Baki Kwarasan Grogol Sukoharjo Jawa Tengah, mobile 085728154514,e-mail fitria.diniah@stikesnas.ac.id 


\section{Pendahuluan}

Kopi merupakan hasil perkebunan dengan nilai ekonomis yang tinggi dan juga berperan penting sebagai sumber pendapatan negara.Kopi juga merupakan salah satu minuman yang digemari di Indonesia. Minuman kopi telah dikonsumsi dari generasi ke generasi hingga sekarang, dari orang tua, dewasa sampai dengan remaja mengkonsumsi kopi.Jumlah konsumsi kopi di Indonesia pada tahun 2018 sebesar $0,801 \mathrm{~kg} / \mathrm{kapita} / \mathrm{tahun}$ (Widaningsih, 2019).

Minuman kopi yang diminum 3-4 gelas setiap harinya dapat mengakibatkan ketergantungan (Maramis, 2013). namun, efek kopi terhadap kesehatan masih diperdebatkan. Beberapa efek positif kopi diantaranya: menurunkan resiko penyakit alzhaimer, parkinson, diabetes mellitus tipe 2, sirosis hepar, kanker gaster, dan menurunkan asam urat darah. Menurut Muhtar (2018) efek negatif kopi yaitu meningkatkan tekanan darah, menimbulkan ulkus peptikum, esophagitis erosif, gangguan ginjal, dan refluks gastroesophagea.

Minuman lain yang digemari oleh masyarakat Indonesia selain kopi adalah teh hitam. Teh hitam dibuat dengan cara fermentasi. Jumlah konsumsi teh di indonesia pada tahun 2018 adalah $0,29 \mathrm{~kg} / \mathrm{kapita} / \mathrm{tahun}$ (Indarti, 2015). Menurut Maramis (2013) teh bermanfaat sebagai pencegahan dan pengobatan penyakit karena bersifat antibakteri dan antioksidan. Dalam teh mengandung kafein yang aman untuk dikonsumsi tetapi jika dikonsumsi secara berlebihan dapat mengakibatkan seseorang mengalami gugup, gelisah, mual, insomnia, dan kejang. Batas maksimum kafein dalam makanan dan minuman yang diizinkan menurut SNI 01-71522006 adalah $150 \mathrm{mg} /$ hari.

Ginjal merupakan organ ekskresi yang sangat penting dalammengeluarkan sisa-sisa metabolisme didalam tubuh, seperti zat-zat toksik yang tidak sengaja masuk ke tubuh yang mengakibatkan ginjal menjadi salah satu organ utama dari efek toksik (Mayori et al., 2013). Proses ekskresi sisa-sisa metabolit di ginjal dapat mengakibatkan kerusakan pada jaringan. Kerusakan bila dibiarkan dapat menyebabkan gagal ginjal yang berakhir dengan kematian.

Berdasarkan penelitian Widodo et al., (2019) menunjukkan bahwa konsumsi kopi yang mengandung kafein dapat menimbulkan perubahan pada gambaran histologi seperti degenerasi lemak, pembengkakan tubular dan piknotik pada organ ginjal tikus wistar.

Berdasarkan penelitian Jean (2010) dapat diketahui bahwa terdapat kerusakan pada tubulus ginjal akibat pemberian teh hitam yang diamati pada ginjal mencit $\mathrm{BALB} / \mathrm{C}$ dengan mengamati adanya penutupan lumen tubulus proksimal, nekrosis sel epitel tubulus proksimal, hialin cast pada tubulus distal dan reaksi inflamasi intersisial didapatkan adanya kerusakan pada tubulus ginjal. Penelitian ini untuk mengetahui efek histopatologis ginjal tikus putih setelah pemberian seduhan kopi (Coffea cenephora) dan teh hitam (Camellia sinensis $\mathrm{L})$.

\section{Metode}

Penelitian ini merupakan penelitian Eksperimental dengan menggunakan metode The Post Test Only Control Group Design. Penelitian ini menggunakan 7 kelompok perlakuan diantaranya 3 kelompok perlakuan kopi 3 kelompok perlakuan teh serta kontrol. Penelitian dilakukan di Laboratorium Farmaologi dan Laboratorium Patologi Anatomi Sekolah Tinggi Ilmu Kesehatan Nasional Surakarta.

Alat-alat yang digunakan pada penelitian ini adalah Timbangan, sonde yang telah dimodifikasi, kertas label, pisau (pemotongan makros), talenan, wadah pengecatan, floating bath, pinset, cassete tissue, mikroskop, mikrotom, cover glass, obyek glass, wadah (berbahan stainless steel), botol air. Bahan yang digunakan pada penelitian ini adalah organ ginjal tikus putih (Rattusnorvegicus), makanan tikus (pellet), $\mathrm{NaCl}, \mathrm{NBF} 10 \%$, kandang, aceton, kertas saring, kopi, teh, entelan, kapas/tisu, formalin 100\%, Alkohol 70\%, 95\%, $100 \%$, xylol, paraffin, Hematoxilin dan eosin dan aquadest.

Prosedur Penelitian: Sebelum penelitian dilakukan, hewan coba di adaptasi coba selama 7 hari di Laboratorium Sitohistoteknologi Sekolah Tinggi Ilmu Kesehatan Nasional Surakarta. Pemberian pakan Pellet dan minum dengan aquadest. Pembagian Kelompok Hewan Percobaan Dan Pemberian Perlakuan.

Setelah masa adaptasi selama 7 hari hewan coba dikelompokkan menjadi 7 kelompok dan diberi perlakuan selama 30 hari. Kelompok 1 sebagai kontrol diberikan aquadest.Kelompok 2 tikus dengan perlakuan diberikan kopi 3 mg/200 gr/Hari secara per oral. Kelompok 3 tikus dengan perlakuan diberikan kopi 6 mg/200 gr/Hari secara per oral. 
Kelompok 4 tikus dengan perlakuan diberikan kopi 12 mg/200 gr/Hari secara per oral. Kelompok 5 tikus dengan perlakuan diberikan teh hitam $3 \mathrm{mg} / 200 \mathrm{gr} / \mathrm{Hari}$ secara per oral. Kelompok 6 tikus dengan perlakuan diberikan teh hitam $6 \mathrm{mg} / 200 \mathrm{gr} / \mathrm{Hari}$ secara per oral. Kelompok 7 tikus dengan perlakuan diberikan teh hitam 12 mg/200 gr/Hari secara per oral.

Jaringan yang diperoleh pada penelitian ini diambil dari hewan tikus yang dipelihara sesuai dengan syarat-syarat hewan coba. Jaringan ginjal tikus sebanyak 28 ekor dipotong dengan ukuran $2 \times 1 \times 0,5 \mathrm{~cm}$ dibagi menjadi 7 kelompok masing-masing 4 potong untuk setiap kelompok kemudian diberi label.

Pengamatan secara makroskopis dilakukan dengan menilai adanya perubahan warna, perubahan struktur dan ukuran organ ginjal.Menurut (Kemenkes, 2019), pemrosesan jaringan histologi dapat dilakukan dengan cara manual ataupun dengan menggunakan mesin otomatis (tissue prosesor). Jaringan dipotong sekitar $5 \mathrm{~mm}$ dilakukan pencucian menggunakan $\mathrm{NaCL}$ dan dimasukkan kedalam cassete tissue dan di fiksasi dengan NBF $10 \%$ selama $1 \frac{1}{2}$ jam, kemudian NBF $10 \%$ selama 1 $1 / 2$ jam.Proses pengeluaran cairan yang terdapat di dalam jaringan dilakukan dengan memasukkan jaringan pada alkohol 50\% selama $1 \frac{1}{2}$ jam, alkohol $70 \%$ selama $1 \frac{1}{2}$ jam, alkohol 95\% selama $1 \frac{1}{2}$ jam, alkohol $95 \%$ selama $1 / 2$ jam, alkohol 100\% selama 2 jam, dan alkohol $100 \%$ selama 2 jam. Digunakan alkohol bertingkat agar tidak terjadi perubahan pada sel jaringan.

Selanjutnya adalah proses clearing. Pada proses ini jaringan dimasukkan kedalam xilol 1 selama 1 jam dan xilol 2 selama 2 jam dilanjutkan dengan meregnation dan embedding yaituaringan dimasukkan kedalam parafin cair 1selama 2 jam dan parafin 2 selama 4 jam, diletakkan pada base mold. Jaringan diposisikan dengan tepat menggunakan pinset dan ditambahkan dengan parafin panas hingga menutupi cetakan dan ditutup dengan cassete tissue. Proses ini dilakukan untuk meletakkan atau memposisikan spesimen sedemikan rupa dengan tujuan agar mudah dalam proses pemotongan mikrotom.

Pemotongan jaringan dari blok dengan ketebalan 3-5 $\mathrm{mm}$ dengan menggunakan mikrotom dan ditangkap dengan objek glass pada floating bath $\left(60^{\circ} \mathrm{C}\right)$. Tahapan pewarnaan HE pertama adalah deparafinisasi dengan memasuksan jaringan dalam xilol, lalu dimasukan kedalam alkohol absolut, alkohol 90\% dan alkohol $70 \%$ untuk proses rehidrasi. Selanjutnya dilakukan perendaman cat hematoksilin, kemudian untuk memperjelas warna biru pada inti sel dimasukan kedalam bluing reagen. Jaringan kemudian direndam cat eosin dan dicuci dengan alkohol. Terakhir jaringan dimasukan dalam xilol untuk selanjutnya dilakukan mounting jaringan dengan entelan/canada balsam. Sediaan ditutup menggunakan cover glass dan dibaca dengan mikroskop cahaya perbesaran 400X dan diamati sebanyak 3 orang pengamat.

Hasil pengamatan dicatat dan melakukan analisa data seingga data dapat disimpulkan.

Penelitian ini telah memenuhi deklarasi Helsinki 1975, Council of International Organization of Medical Science (CIOMS) dan World Health Organization (WHO) 2016 dan dinyatakan lolos etik.

\section{Hasil}

Berdasarkan hasil pengamatan yang telah dilakukan secara makroskopis (Tabel 1.) dapat diketahui bahwa tidak ada perbedaan antara perlakuan seduhan kopi dan teh terhadap kontrol. Pengamatan makroskopis dilakukan dengan menilai warna, tekstur dan ukuran organ ginjal. Semua perlakuan memiliki warna yang sama yaitu merah kecoklatan, tekstur kenyal dan memiliki ukuran dengan panjang $1,5 \mathrm{~cm}$ dan lebar $1 \mathrm{~cm}$.

Pada pengamatan organ ginjal tikus putih secara mikroskopis yang diberikan perlakuan seduhan kopi dan teh di lakukan dengan mengamati dan memberi skoring adanya degenerasi, nekrosis (sel piknotik, karioreksis, kariolisis ) sebanyak 5 lapang pandang dengan perbesaran 400x. Pengamatan dilakukan oleh 3 orang pengamat. Hasil pengamatan yang dilakukan secara mikroskopis didapatkan adanya degenerasi, piknotik dan karioreksis pada semua seduhan kopi dan teh K2, K3, K4, K5,K6 dan K7 (Gambar 3. sampai gambar 8).

Berikut merupakan gambaran makroskopis Ginjal Tikus Putih (Rattus norvegicus).

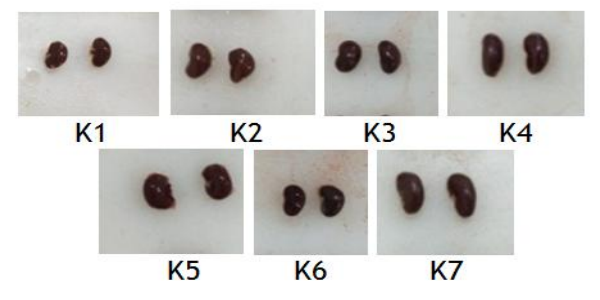

Gambar 1. Hasil Pemeriksaan gambaran makroskopis ginjal tikus putih (Rattus norvegicus) K1: Tanpa Perlakuan, K2:Seduhan Teh $3 \mathrm{mg} / 200 \mathrm{gram} / \mathrm{hari}$, 
K3:Seduhan Teh $6 \mathrm{mg} / 200 \mathrm{gram} / \mathrm{hari}$, K4:Seduhan Teh $12 \mathrm{mg} / 200$ gram/hari, K5:Seduhan Kopi 3 mg/200gram/hari, K6:Seduhan Kopi 6 mg/200gram/hari, K7:SeduhanKopi $12 \mathrm{mg} / 200 \mathrm{gram} / \mathrm{hari}$

Tabel 1. Hasil Pengamatan Jaringan Ginjal Secara Makroskopis

\begin{tabular}{ccccc}
\hline \multirow{2}{*}{ Kel } & Warna & Tekstur & \multicolumn{2}{c}{ Ukuran } \\
\cline { 4 - 5 } Kontrol & $\begin{array}{c}\text { Merah } \\
\text { kecoklatan }\end{array}$ & Kenyal & $1,5 \mathrm{~cm}$ & $1 \mathrm{~cm}$ \\
\hline Kopi 3 & $\begin{array}{c}\text { Merah } \\
\text { kecoklatan }\end{array}$ & Kenyal & $1,5 \mathrm{~cm}$ & $1 \mathrm{~cm}$ \\
\hline Kopi 6 & $\begin{array}{c}\text { Merah } \\
\text { kecoklatan }\end{array}$ & Kenyal & $1,5 \mathrm{~cm}$ & $1 \mathrm{~cm}$ \\
\hline Kopi 12 & $\begin{array}{c}\text { Merah } \\
\text { kecoklatan }\end{array}$ & Kenyal & $1,5 \mathrm{~cm}$ & $1 \mathrm{~cm}$ \\
\hline Teh 3 & $\begin{array}{c}\text { Merah } \\
\text { kecoklatan }\end{array}$ & Kenyal & $1,5 \mathrm{~cm}$ & $1 \mathrm{~cm}$ \\
\hline Teh 6 & $\begin{array}{c}\text { Merah } \\
\text { kecoklatan }\end{array}$ & Kenyal & $1,5 \mathrm{~cm}$ & $1 \mathrm{~cm}$ \\
\hline Teh 12 & $\begin{array}{c}\text { Merah } \\
\text { kecoklatan }\end{array}$ & Kenyal & $1,5 \mathrm{~cm}$ & $1 \mathrm{~cm}$ \\
\hline
\end{tabular}

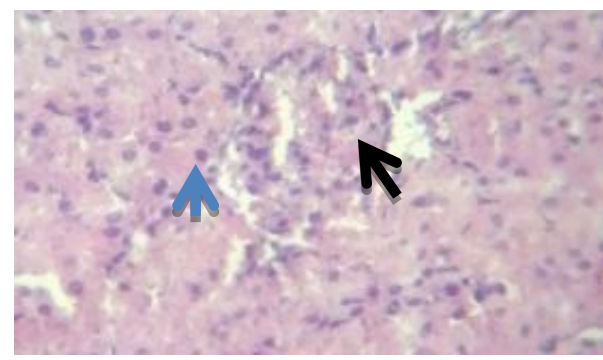

Gambar 2. Gambaran mikroskopis ginjal tikus putih (Rattus norvegicus) panah hitam: Glomerulus, panah biru: inti sel Hasil Pemeriksaan Bakteri secara Mikroskopis Kelompok Kontrol (K1) Perbesaran 400x.

Hasil pengamatan mikroskopis pada kelompok kontrol (K1) (Gambar 2.)menunjukkan gambaran mikroskopis ginjaltampak inti sel berbentuk bulat berwarna ungu, sitoplasma berwarna merah dan terdapat adanya Glomerulus.

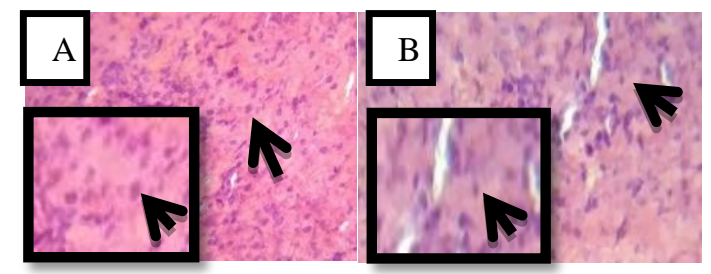

Gambar 3. Gambaran mikroskopis ginjal tikus putih (Rattus norvegicus) A: degenerasi, B: piknotik Kelompok 2 (K2) kopi 3 mg/200 gram/hari perbesaran 400x.
Pada kelompok K2 sel tampak membesar (A), inti sel mengecil, mengkisut, warna menjadi lebih gelap (B).

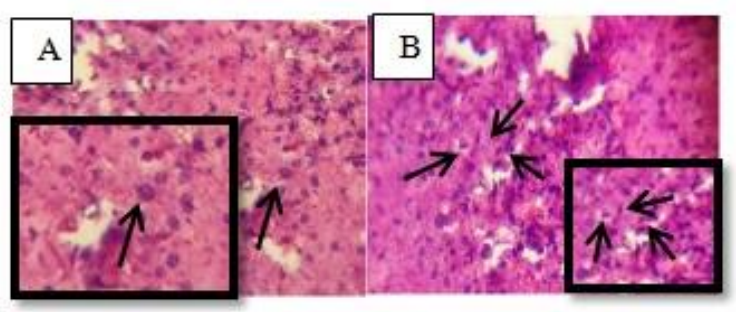

Gambar 4. Gambaran Mikroskopis Ginjal Tikus Putih (Rattus norvegicus) A: Degenerasi B: Piknotik kelompok 3 (K3) kopi 6 mg perbesaran 400x.

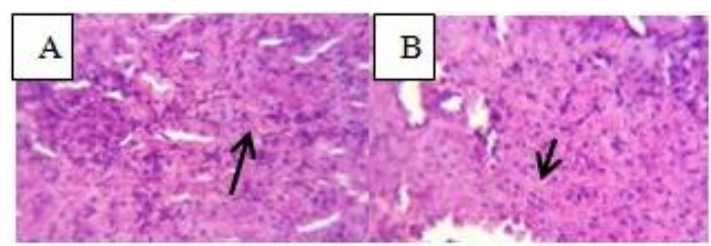

Gambar 5. Gambaran Mikroskopis Ginjal Tikus Putih (Rattus norvegicus)A: Degenerasi B: PiknotikKelompok 4 (K4) kopi 12 mg perbesaran 400x.

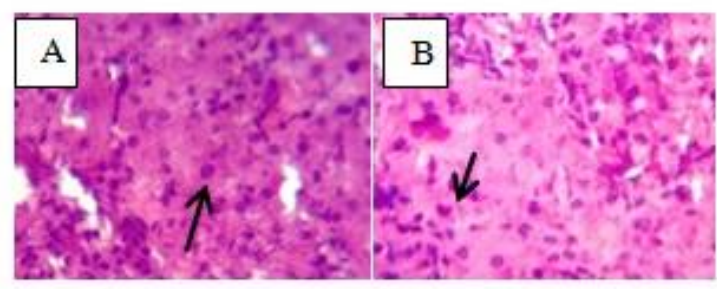

Gambar 6. Gambaran Mikroskopis Ginjal Tikus Putih (Rattus norvegicus)A: Degenerasi B:PiknotikKelompok 5 (K5) Teh $3 \mathrm{mg}$ perbesaran 400x.

Pada kelompok K5 didapatkan inti membesar (A) dan mengkisut (B).

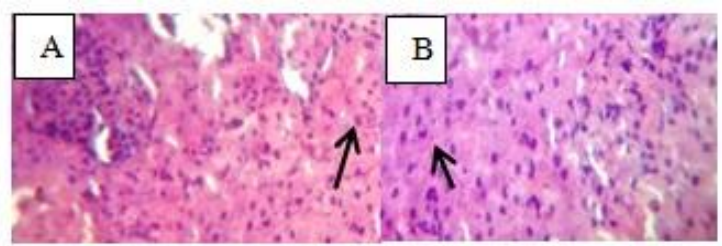

Gambar 7. Gambaran Mikroskopis Ginjal Tikus Putih (Rattus norvegicus) A: Degenerasi B: Piknotik Kelompok 6 Teh $6 \mathrm{mg}$ perbesaran 400x.

Pada kelompok K6 didapatkan adanya inti membesar (A), inti tampak keriput dan warna lebih gelap (B). 


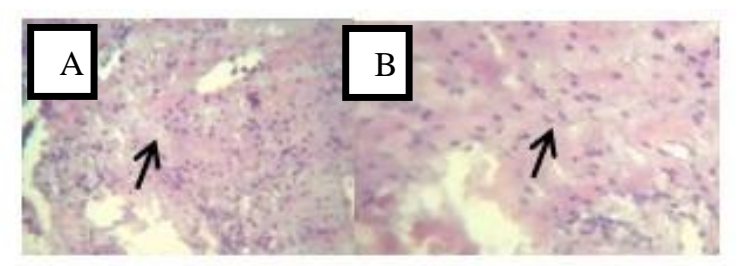

Gambar 8. Gambaran Mikroskopis Ginjal Tikus Putih (Rattus norvegicus)A: Degenerasi B: PiknotikKelompok 7 (K7) Teh $12 \mathrm{mg}$ perbesaran 400x.

\section{Pembahasan}

Pada penelitian ini menggunakan dosis 3 $\mathrm{mg}, 6 \mathrm{mg}$ dan $12 \mathrm{mg}$ dilarutkan kedalam aquadest sehingga terdapat $1 / 4$ bagian $(0,6 \mathrm{mg}$, $1,2 \mathrm{mg}$ dan 2,4 mg) pada larutan $3 \mathrm{mg}, 6 \mathrm{mg}$ dan $12 \mathrm{mg}$ yang tidak dapat larut secara sempurna (menjadi endapan) karena adanya titik jenuh dalam larutan. Titik jenuh larutan adalah suatu titik dimana penambahan partikel perlarut sudah tidak dapat menyebabkan partikel melarut sehingga menimbulkan larutan jenuh. Larutan jenuh sendiri merupakan larutan pada zat terlarut padabatas kelarutannya dengan fase pelarutnya (Sinala, 2016). Endapan yang terjadi pada larutan tidak dimasukkan karena hanya seduhan yang diberikan maka endapan tidak ikut diberikan ke tikus sehingga dosis yang sebenarnya masuk ke dalam tikus adalah 2,4 mg (dosis $3 \mathrm{mg}$ ), 4,8 $\mathrm{mg}$ (6 mg) dan 9,6 mg (12mg).

Berdasarkan hasil pengamatan pada perlakuan 1 (K1) (Gambar 2.) ditemukan adanya kerusakan berupa nekrosis dalam jumlah yang kecil, hal ini bisa saja terjadi pada perlakuan 1 (K1) sebagai kontrol karena adanya proses kematian sel secara fisiologis oleh semua sel hidup. Setiap sel yang ada didalam tubuh akan mengalami proses penuaan atau kematian dan sel yang mengalami penuaan akan mati dan diganti dengan sel yang baru dengan regenerasi (Anggriani, 2008). Pada seduhan kopi 3 mg/200 gr/hari kelompok (K2) pada (Gambar 3.) hasil pengamatan yang didapat berupa degenerasi (inti tampak membesar) ditemukan juga adanya nekrosis dalam jumlah yang kecil berupa piknotik yang ditandai dengan inti sel yang mengecil (mengkisut) dan warna berubah menjadi lebih gelap. Pengamatan kelompok 3 (K3) kopi 6 mg/200 gr/hari (Gambar 4.) ditemukan adanya degenerasi berupa pembengkakan sel dan juga ditemui adanya nekrosis (piknotik) dengan inti sel yang mengkisut (mengalami berubah bentuk). pada pengamatan kelompok 4 (K4) kopi 12 mg/200 gr/hari (Gambar 5.) ditemukan adanya degenerasi dan nekrosis. Nekrosis ditemui hampir disetiap lapang pandang. Pada kelompok 5 (K5) (Gambar 6.) perlakuan seduhan teh $3 \mathrm{mg} / 200 \mathrm{gr} / \mathrm{hari}$ cenderung ke arah degenerasi terdapat juga adanya nekrosis dalam jumlah yang kecil pada kelompok 6 (K6) (Gambar 7.) perlakuan seduhan teh $6 \mathrm{mg} / 200$ gr/hari mulai tampak adanya peningkatan jumlah degenerasi dan piknotik sedangkan pada kelompok 7 (K7) (Gambar 8.) perlakuan seduhan teh $12 \mathrm{mg} / 200 \mathrm{gr} / \mathrm{hari}$ menjadi dosis seduhan yang memberikan efek paling besar dengan hasil skor 3 hampir disetiap lapang pandang ditandai dengan adanya jumlah nekrosis berupa piknotik.

Degenerasi dan nekrosis pada pengamatan mikroskopis ginjal terjadi akibat adanya senyawa-senyawa sitotoksik yang masuk kedalam ginjal dimana, fungsi ginjal sebagai organ ekskresi zat metabolisme dalam tubuh, seperti zat toksik yang tidak sengaja masuk kedalam tubuh dan menyebabkan ginjal menjadi organ utama dari efek toksik (Mayori et al., 2013). Degenerasi sendiri merupakan keadaan terhadap perubahan morfologi sel akibat zat toksik, penimbunan cairan atau berkurangnya suplai darah karena terjadi penyumbatan (Suyanti, 2008).Nekrosis adalah tahap lanjut dari degenerasi dimulai dengan tahap piknotik (inti yang mengental), karioreksis (pecah) dan kariolisis (hancur) (Hidayat, 2018). Piknotik merupakan keadaan dimana inti sel mengecil, mengkisut dan warna menjadi lebih gelap (Adinanta dan Sudira, 2012)

Tubuh terdiri dari kesatuan dasar yang disebut sel, setiap sel akan berkelompok membentuk jaringan dan setiap jaringan akan saling berhubungan membentuk organ. Untuk mempertahankan hidup sel memiliki kemampuan untuk beradaptasi. Respon sel yang mengalami cedera dapat bersifat reversibel dan ireversibel. Bentuk adaptasi sel yaitu dengan hipertrofi (menambah ukuran sel), atropi (mengurangi ukuran sel), hyperplasia (menambah jumlah sel) dan merubah sel (metaplasia). Setiap sel pada mahluk hidup akan mengalami kematian, kematian sel sendiri dibagi menjadi 2 yaitu nekrosis dan apoptosis. Nekrosis diawali dengan piknotik (inti sel mengalami penyusutan, tampak lebih padat berwarna gelap dan batas tidak teratur) karioreksis (inti sel hancur, terdapat kromatin yang pecah) dan kariolisis(inti menghilang). Sedangkan apoptosis adalah kematian sel yang terprogram. Apoptosis digunakan oleh tubuh untuk membuang sel yang mati dan diganti 
dengan sel yang baru.Apoptosis bersifat menguntungkan dan berlangsung umur hidup (Sriyanti, 2016).

Sesuai dengan hasil penelitian sebelumnya yang dilakukan oleh (Widodo \& Utami, 2019) menunjukkan bahwa konsumsi kopi berkafein dapat menimbulkan perubahan pada gambaran histologi seperti degenerasi lemak, pembengkakan tubular dan piknotik pada organ ginjal tikus wistar. Dan berdasarkan penelitian Jean (2010) terdapat kerusakan pada tubulus ginjal akibat pemberian teh hitam yang diamati pada ginjal mencit BALB/C seperti penutupan lumen tubulus proksimal, nekrosis sel epitel tubulus proksimal, hialin cast pada tubulus distal dan reaksi inflamasi intersisial didapatkan adanya kerusakan pada tubulus ginjal.

Berdasarkan hasil penelitian ini dapat disimpulkan bahwa terdapat perbedaan yang signifikan antara kelompok perlakuan seduhan kopi dan teh dengan kelompok kontrol berdasarkan uji statistik menggunakan SPSS pada uji Mann-Whitney. Seduhan kopi dan teh memberikan efek terhadap gambaran histopatologi ginjal tikus putih Rattus norvegicus berupadegenerasi dan piknotik.

Saran bagi penelitian selanjutnya dapat menggunakan kontrol positif dan kontrol negatif, serta penelitian ini dapat memberikan informasi pada masyarakat umummengenai efek konsumsi kopi dan teh hitam secara berlebihan.

\section{Daftar Pustaka}

Hidayat, M. (2018). Monograf Hidrolisat Protein Kacang Polong (Pisum sativum L) Untuk Terapi Peenyakit Ginjal Kronik (1st ed.). Alfabeta.

Indarti， D. (2015). Outlook Teh Komoditas Pertanian Subsektor Perkebunan. Sekretariat Jenderal Kementrian Pertanian, Pusat Data Dan Sistem Informasi Pertanian, 1, 90. http://epublikasi.setjen.pertanian.go.id/epu blikasi/outlook/2015/Perkebunan/Outlook Teh

2015/files/assets/common/downloads/Outl ook Teh 2015.pdf

Jean, R. (2010). Pengaruh Pemberian Teh Hitam (Camellia Sinensis) Terhadap Gambaran Histopatologi Ginjal Mencit Balb/C.
Kemenkes, R. (2019). Panduan Penatalaksanaan Kanker Payudara. Jurnal Kesehatan Masyarakat, 4(4), 1-50. http://kanker.kemkes.go.id/guidelines/PP KPayudara.pdf

Made Oka Adinata, I Wayan Sudira, I. K. B. (2012). Efek Ekstrak Daun Ashitaba (Angelica keiskei) Terhadap Gambaran Histopatologi Ginjal Mencit (Mus musculus) Jantan. Buletin Veteriner Udayana, 4(2), 55-62.

Maramis, R. K. (2013). Analisis Kafein Dalam Kopi Bubuk Di Kota Manado Menggunakan Spektrofotometri Uv-Vis. Jurnal Ilmiah Farmasi, 2.

Mayori, R., Marusin, N., \& Tjong, H. (2013). Pengaruh Pemberian Rhodamin B Terhadap Struktur Histologis Ginjal Mencit Putih ( Mus musculus L .) Effects of rhodamin $B$ on the kidney histological structure of white mice (Mus musculus $L$ .). 2(1), 43-49.

Muhtar, A. (2018). Pengaruh Pemberian Kopi Terhadap Waktu Perdarahan (Bleeding Time) Pada Mencit (Mus musculus).

Sinala, S. (2016). Farmasi Fisik bahan Ajar Cetak Farmasi.

Sriyanti. (2016). Patologi 1st ed (Suyanto,ed) Kementrian Kesehatan Republik Indonesia.

Suyanti, L. (2008). Pada Pemberian Fraksi Asam Amino Non-Protein Pada Uji Toksisitas Akut Lilis Suyanti Fakultas Kedokteran Hewan.

Widaningsih, R. (2019). Buku Outlook Komoditas Perkebunan Kopi. Pusat Data Dan Informasi Pertanian Sekretariat JendralKementrian Pertanian.

Widodo, I. P., \& Utami, D. T. (2019). The Effect of High Temperature Roasted Coffea liberica on Physiological and Histological Structure of Mice 's Kidney. 10(1), 30-36. 